\title{
Australian Journal of Crop Science \\ Effect of nitrogen source and oxygen deficiency on carbon metabolism and antioxidant system of rubber tree plants (Hevea spp.)
}

\section{Pollyanna Aparecida de Carvalho ${ }^{1}$, Luiz Edson Mota de Oliveira ${ }^{1}$, Débora Domiciano ${ }^{1}$, Jullyanna Nair de Carvalho $^{2}$, Débora de Oliveira Prudente ${ }^{1}$, Rubens José Guimarães ${ }^{3}$}

\author{
${ }^{1}$ Fisiologia Vegetal, Departamento de Biologia, Universidade Federal de Lavras, Lavras, Minas Gerais, Brasil \\ ${ }^{2}$ Universidade Federal do Vale do São Francisco, Petrolina, Pernambuco, Brasil \\ ${ }^{3}$ Departamento de Agricultura, Universidade Federal de Lavras, Lavras, Minas Gerais, Brasil
}

*Corresponding author: pollycarvalhoufla@yahoo.com.br

\begin{abstract}
Oxygen deficiency in roots affects key functions such as nutrient and water uptake; furthermore, liquid- $\mathrm{CO}_{2}$ assimilation, stomatal conductance/ transpiration and carbohydrate translocation are also affected. Under oxygen depletion, there is also an uncontrolled increase of free radicals in cells. The nitrogen application has been observed to increase the plant tolerance to oxygen deficiency. Indeed, $\mathrm{NO}_{3}{ }^{-}$and $\mathrm{NH}_{4}{ }^{+}$(nitrogen forms) may induce distinct metabolic responses under hypoxia. Nevertheless, the beneficial effects of $\mathrm{N}$ during hypoxia it is not fully explained. In this study, the nitrogen $(\mathrm{N})$ role in the physiology and metabolism of rubber plants (Hevea brasiliensis) subjected to oxygen deficiency was evaluated. The experiment was conducted with plants supplied with $\mathrm{KNO}_{3}(8 \mathrm{mM} \mathrm{N})$ or $\left(\mathrm{NH}_{4}\right)_{2} \mathrm{SO}_{4}(8 \mathrm{mM} \mathrm{N})$ in nutrient solution for 3 days. The experiments were arranged in a completely randomized design (CRD) in a factorial arrangement $(2 \times 2 \times 4)$. The experiment had four treatments and four time points $(12,24,48$ and 72 hours) for stress measurements with four replicates, totaling 64 plants. Data were analyzed using analysis of variance (ANOVA), and the means were compared using the Scott-Knott test $(p \leq 0.05)$. Gas exchange measurements and biochemical analyzes were performed at 12, 24, 48 and 72 hours after treatment induction. The results showed that, net photosynthesis, stomatal conductance and transpiration rate in stressed plants decreased significantly when compared to the control plants, regardless of nitrogen source. However, under hypoxia, plants treated with $\mathrm{NO}_{3}{ }^{-}$showed significantly higher $\mathrm{CO}_{2}$ assimilation, overcoming the treatment with $\mathrm{NH}_{4}^{+}$. Therefore, when comparing plants treated with $\mathrm{NO}_{3}{ }^{-}$and those treated with $\mathrm{NH}_{4}^{+}$under flooding conditions (for 3 days), the first presented higher sucrose production, consequently higher invertase isoform activity. Under hypoxia, $\mathrm{NO}_{3}{ }^{-}$ treated plants also showed higher antioxidant system efficiency. Therefore, $\mathrm{H}_{2} \mathrm{O}_{2}$ content was higher in plants treated with $\mathrm{NH}_{4}^{+}$. Thus, we concluded that carbon metabolism such as carbohydrate anabolism, catabolism and transport were negatively affected by hypoxia. However, $\mathrm{NO}_{3}{ }^{-}$addition in contrast to $\mathrm{NH}_{4}{ }^{+}$treatment reduced damage caused by oxygen deficiency increasing the level of tolerance of the plant to stress.
\end{abstract}

Keywords: Hevea brasiliensis, Nitrogen, Oxygen deficiency, Carbohydrates metabolism, Invertase isoforms, Antioxidant enzymes. Abbreviation: SOD_Superoxide dismutase, CAT_catalase, APX_ascorbate peroxidase, NR_nitrate reductase, ROS_reactive oxygen species, $P_{\mathrm{N}}$ net $\mathrm{CO}_{2}$ assimilation rate, $g_{\mathrm{S} \_}$stomatal conductance, E_transpiration, PPFD_photosynthetic photon flux density, VIN_vacuolar invertase, NIN_neutral invertase, CWIN_cell wall invertase.

\section{Introduction}

Oxygen deficiency and low soil redox potential, induced by flooding, negatively affect several aspects of plant physiology, such as changes in carbon assimilation, macronutrient and water absorption, carbohydrate translocation, suppression of the respiratory metabolism of the roots, causing decline in rate ATP / ADP (Kreuzwieser et al., 2004). In addition, hypoxic conditions affect the terminal receptor of the mitochondrial respiratory chain, resulting in the inhibition of demanding energy processes (Bailey-Serres and Voesenek, 2008). From the moment that the oxygen concentration present becomes insufficient to maintain the normal rate of root respiration, by definition, the system enters the state of hypoxia. Given the fundamental importance of $\mathrm{O}_{2}$ in aerobic plants metabolism, waterlogging stress can strongly affect growth and survival in both agricultural and natural ecosystems. Indeed, $\mathrm{O}_{2}$ depletion can negatively influence the productivity of many economically important species (Irfan et al., 2010).

Throughout the evolutionary process, tolerant species developed a variety of strategies that enabled them to occupy areas subject to flooding. Among these strategies, morpho-anatomical changes occur that aid the internal plant aeration, and metabolic alterations, such as decrease in energy consumption and less investment in growth (Medri et al. 2007). In most species, the success strategy combines morphological, anatomical, and physiological responses. In general these responses may include reduced growth and development of plants (Kozlowski 1997), the stomatal closure and the decrease in photosynthesis and transpiration rate, as well as changes in the transport and partitioning of photoassimilates (Kreuzwieser et al. 2004), 
and changes in the action of the plants antioxidant system (Jaleel et al. 2009). Currently, the positive effect of nitrogen addition on the roots of flooded plants is known, however, the effect of interaction between hypoxia and carbon and nitrogen metabolism is still not completely understood (Carvalho et al., 2015a). It is known that the application of nitrate $\left(\mathrm{NO}_{3}{ }^{-}\right)$has been observed to increase the tolerance of plant species subjected $\mathrm{O}_{2}$ deficiency (Allegre et al. 2004; Thomas and Sodek 2005; Horchani et al. 2010; de Carvalho et al. 2015b). Indeed, comparisons of $\mathrm{NO}_{3}{ }^{-}$and $\mathrm{NH}_{4}{ }^{+}$indicate that these nitrogen forms may induce distinct metabolic responses under water stress and hypoxia (Escobar et al., 2006; Patterson et al., 2010). At the whole plant level, however, maintaining the metabolism of sugars at appropriate levels, followed by correct partitioning of these molecules associated with energy, are prerequisites for survival to adverse conditions (Goggin, 2007). Invertase (EC 3.2.1.26) hydrolyzes sucrose into glucose and fructose and plays a major role in plant development and in response to biotic and abiotic stresses (Essmann et al. 2008). The resultant hexoses are both important signaling molecules for regulating gene expression and essential substrates for energy (ATP) generation and various metabolic and biosynthetic processes, including starch and cellulose synthesis (Rolland et al. 2006). Since sucrose catabolism interferes in the cellular redox state, influencing the coordination of carbon and nitrogen metabolism (NunesNesi et al. 2010).

Stress caused by low oxygen availability also leads to an increase of free radicals in cells, vary according to the species and to the severity and duration of stress (Hong-Bo et al. 2008). Tolerates plants increased SOD activity, which determines $\mathrm{O}_{2}^{-}$and $\mathrm{H}_{2} \mathrm{O}_{2}$ concentration - key defense mechanisms necessary to prevent the $\mathrm{OH}^{-}$radical formation (Jaleel et al. 2009). Among enzymes involved in ROS deletion, SOD is considered a key enzyme because it is the first line of defense against oxidative stress (Pompeu et al. 2008). Plants have developed a complex enzymatic defense system as a protective strategy against oxidative damage. Key constituents of this system include superoxide dismutase (SOD), that catalyzes the conversion of superoxide anion into $\mathrm{H}_{2} \mathrm{O}_{2}$ and $\mathrm{O}_{2}$, catalase (CAT) and ascorbate peroxidase (APX), that can break down $\mathrm{H}_{2} \mathrm{O}_{2}$ to $\mathrm{H}_{2} \mathrm{O}$ and $\mathrm{O}_{2}$ (Jaleel et al., 2009). The removal of ROS has a direct influence on the metabolism of nitrogen, as well as photosynthesis and carbohydrate metabolism as a whole is affected by the poll of free radicals in the cell (Carvalho et al. 2015a). Therefore, the objective of this study was to identify physiological (gas exchanges) and metabolic (enzymatic activity) rubber tree plants (Hevea brasiliensis Müll. Arg.) responses under hypoxia and nitrogen (sources: $\mathrm{NO}_{3}{ }^{-}$or $\mathrm{NH}_{4}{ }^{+}$). The mechanisms of tolerance to hypoxia, were studied, by gas exchange evaluation and carbohydrates metabolism and antioxidant system analysis in the leaves and roots.

\section{Results}

\section{Dry weight and chlorophyll content}

After 72 hours of the experiment, seedlings did not show significant differences in shoot or root dry weight; this characteristic remained at the same level throughout the experiment Fig. 1. The dry weight of shoot was, on average, $30 \mathrm{~g}$ per plant Fig. $1 \mathrm{~A}$, while dry weight of root was $12 \mathrm{~g}$ per plant Fig. 1B. Root dry weight did not increase in the control treatment and did not increase after 72 hours in the hypoxic treatment. Rubber tree seedlings subjected to hypoxia showed significant decreases in the levels of chlorophyll, whose values then remained constant until the end of the experiment Fig. 1C. In contrast, the levels of this pigment remained unchanged in control seedlings. The controls maintained their chlorophyll concentration $\left(0.035 \mathrm{mg} . \mathrm{cm}^{-2}\right)$. Throughout the experiment, the values of chlorophyll were $15 \%$ lower in oxygen deficient seedlings when compared to control regardless of nitrogen source.

\section{Gas exchange}

Variance analysis for net photosynthetic rate $(A)$, ratio between internal carbon and external carbon $(\mathrm{Ci} / \mathrm{Ca})$, transpiration rate (E) and stomatal conductance (gs) indicates significance for interaction nitrogen source versus $\mathrm{O}_{2}$ availability, to these four evaluated variables (Fig 2). In both nitrogen treatments, plants under normoxia had higher photosynthesis. Treatment with $\mathrm{NO}_{3}{ }^{-}$, photosynthesis decreased from $4.0 \mu \mathrm{mol} \mathrm{CO}_{2} \cdot \mathrm{m}^{-2} \cdot \mathrm{s}^{1}$ under normoxia to 2.0 under hypoxia, down of $50 \%$. In the presence of $\mathrm{NH}_{4}{ }^{+}$, the decrease in this variable is even greater than $5.0 \mu \mathrm{mol}$ $\mathrm{CO}_{2} \cdot \mathrm{m}^{-2} \cdot \mathrm{s}^{-1}$ to 1.2 it is drop of $76 \%$ (Fig. $2 \mathrm{~A}$ ). Similarly, the ratio $\mathrm{Ci} / \mathrm{Ca}$ (Fig. 2B) was significantly reduced when the root system was subjected to hypoxia. The decreases were 0.6 to 0.4 in $\mathrm{NH}_{4}{ }^{+}$treatment and 0.8 to 0.5 in $\mathrm{NO}_{3}{ }^{-}$treatment. Stomatal conductance as well as $\mathrm{A}$ and ratio $\mathrm{Ci} / \mathrm{Ca}$, was adversely affected by $\mathrm{O}_{2}$ deficiency it was found (Fig. 2C). A reduction of approximately $50 \%$ in plants under flooding, regardless nitrogen source applied in solution was found. Plants treated with $\mathrm{NO}_{3}{ }^{-}$, there was a reduction of $0.04 \mathrm{~mol}$ $\mathrm{H}_{2} \mathrm{O} . \mathrm{m}^{-2} . \mathrm{s}^{-1}$ to 0.02 , while in the treatment with $\mathrm{NH}_{4}^{+}$thr gs decreased from $0.07 \mathrm{~mol} \mathrm{H}_{2} \mathrm{O} \cdot \mathrm{m}^{-2} \cdot \mathrm{s}^{-1}$ to 0,035 . Under normoxia, transpiration rate showed values of $2.2 \mathrm{mmol}$ $\mathrm{H}_{2} \mathrm{O} . \mathrm{m}^{-2} . \mathrm{s}^{-1}$ and 3.6 , while under hypoxia, the results reduced (approximately 50\%) to $1.0 \mathrm{mmol} \mathrm{H}_{2} \mathrm{O} . \mathrm{m}^{-2} \cdot \mathrm{s}^{-1}$ and $1.7 \mathrm{in}$ treatment with $\mathrm{NO}_{3}^{-}$and $\mathrm{NH}_{4}^{+}$respectively (Fig. 2D).

\section{Carbohydrate metabolism}

\section{Invertase isoforms activity}

The activity of all isoforms of invertase on leaves and in the roots and regardless of the source, was reduced under flooding. In addition, under $\mathrm{O}_{2}$ deficit, in all evaluations, and in both tissues, the results obtained with $\mathrm{NO}_{3}{ }^{-}$were greater than to the results with $\mathrm{NH}_{4}^{+}$(Figs. 3 and 4). In leaf tissues, the activities of the three isoforms of invertase were higher than in root tissue. The vacuole acid invertase (VIN) (Figs. 3A and $4 \mathrm{~A}$ ) and the neutral cytosol invertase (NIN) (Figs. 3B and $4 \mathrm{~B})$ showed lower activities compared to acid invertase cell wall (CWIN) (Figs. 3C and 4C). As shown in Figs. 3 and 4, the VIN activity, in plants with $\mathrm{NO}_{3}{ }^{-}$reduced on average by $44 \%$ in the leaf, and $40 \%$ at the root. Already in plants with $\mathrm{NH}_{4}^{+}$ these reductions reached 57 and $67 \%$ respectively. As mentioned above, the NIN was higher than in plants under normoxia. Under hypoxic, differences were observed between treatments with $\mathrm{NO}_{3}{ }^{-}$and $\mathrm{NH}_{4}^{+}$. Under hypoxia, in leaves and roots, $\mathrm{NO}_{3}^{-}$treatment was higher than to 

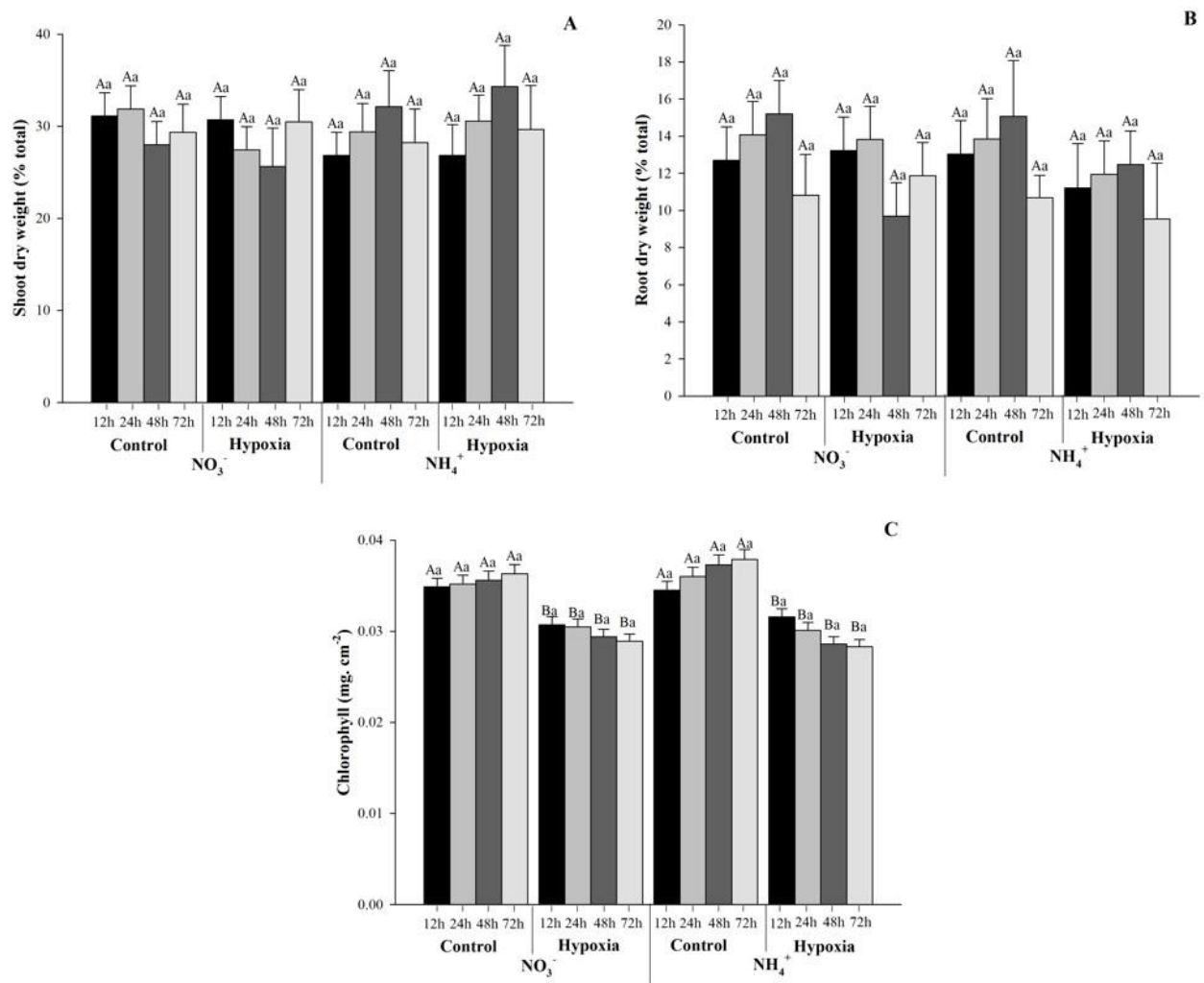

Fig 1. Effect of oxygen availability and of the nitrogen source on shoot (A) and root (B) dry weight and chlorophyll content (C) of rubber tree seedlings. Capital letters compare oxygen availability (control and hypoxia) at each sampling time (12, 24, 48 and 72 hours) within each nitrogen source $\left(\mathrm{NO}_{3}{ }^{-}\right.$and $\left.\mathrm{NH}_{4}{ }^{+}\right)$, whereas lowercase letters compare the nitrogen sources at each sampling time within each oxygen condition. Different letters indicate significant differences with 0.05 probability.
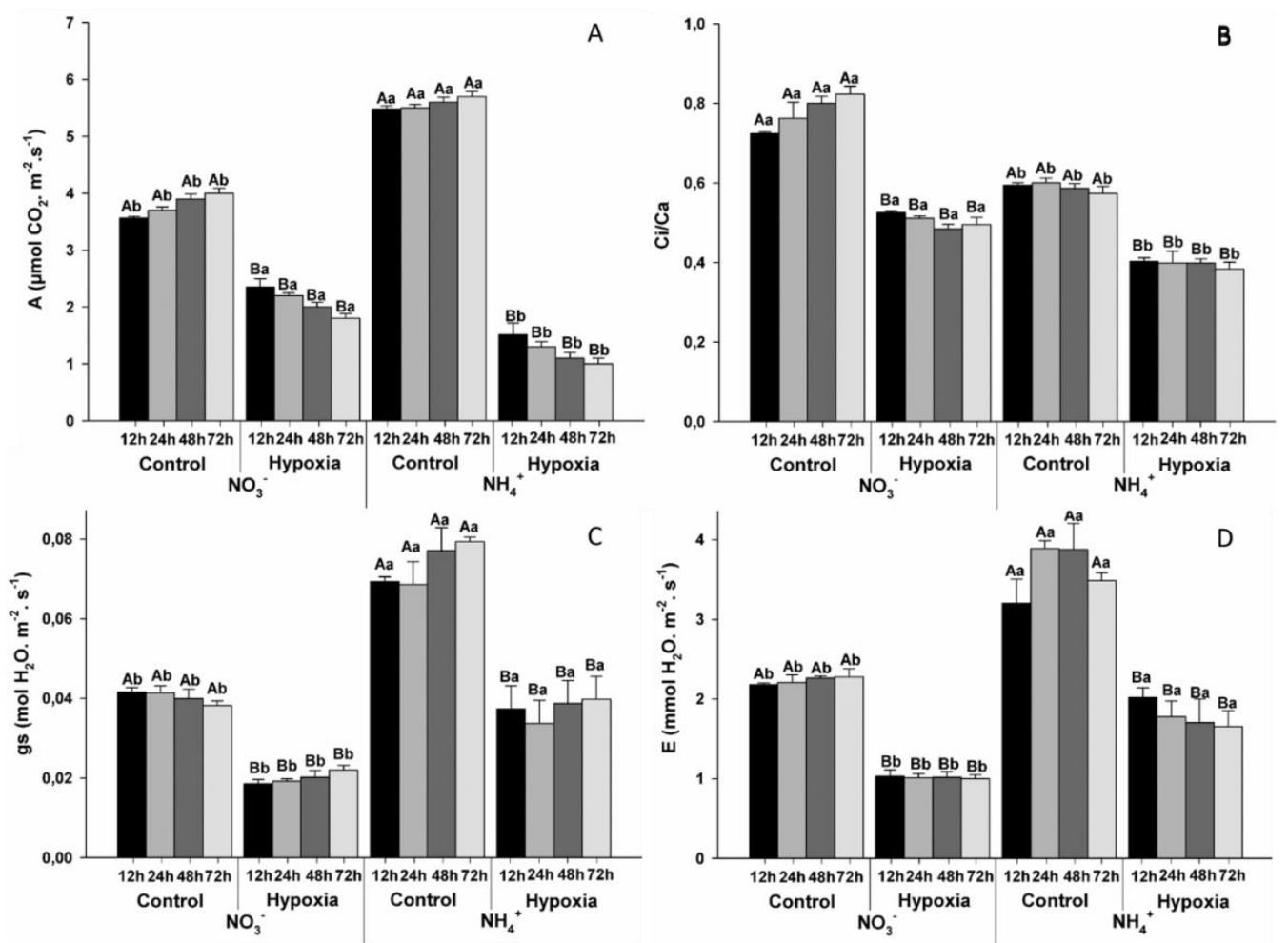

Fig 2. Effect of oxygen availability and of the nitrogen source on net assimilation rate (A), ratio $\mathrm{Ci} / \mathrm{Ca}$ (B), stomatal conductance (C) and transpiration (D) of rubber tree seedlings. Capital letters compare oxygen availability (control and hypoxia) at each sampling time $\left(12,24,48\right.$ and 72 hours) within each nitrogen source $\left(\mathrm{NO}_{3}{ }^{-}\right.$and $\left.\mathrm{NH}_{4}{ }^{+}\right)$, whereas lowercase letters compare the nitrogen sources at each sampling time within each oxygen condition. Different letters indicate significant differences with 0.05 probability. 

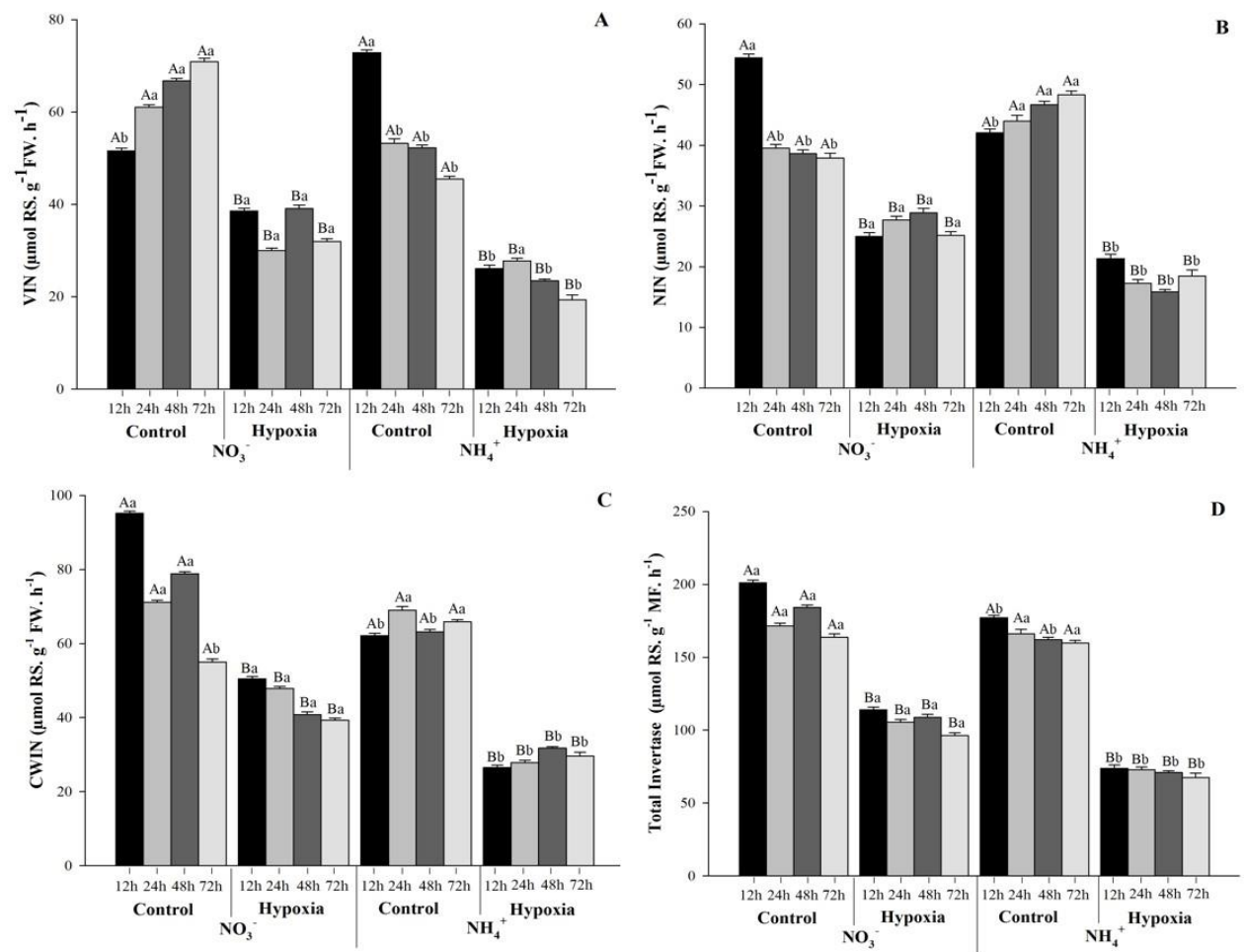

Fig 3. Effect of oxygen availability and of the nitrogen source in the activity of the enzymes vacuolar invertase (A), neutral invertase (B), cell wall invertase (C) and total invertase (D), in leaf of rubber tree seedlings. Capital letters compare oxygen availability (control and hypoxia) at each sampling time $\left(12,24,48\right.$ and 72 hours) within each nitrogen source $\left(\mathrm{NO}_{3}{ }^{-}\right.$and $\left.\mathrm{NH}_{4}{ }^{+}\right), \mathrm{whereas}$ lowercase letters compare the nitrogen sources at each sampling time within each oxygen condition. Different letters indicate significant differences with 0.05 probability.
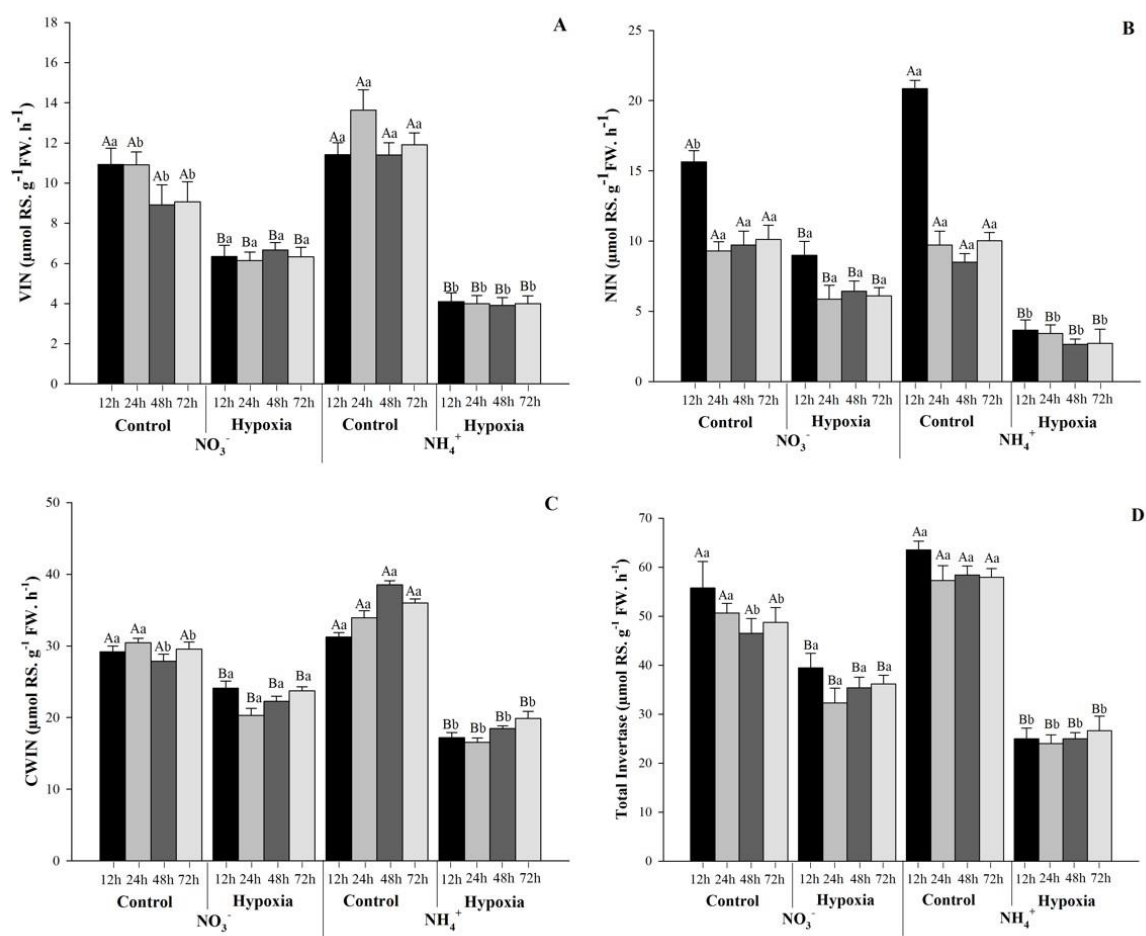

Fig 4. Effect of oxygen availability and of the nitrogen source in the activity of the enzymes vacuolar invertase (A), neutral invertase (B), cell wall invertase (C) and total invertase (D), in roots of rubber tree seedlings. Capital letters compare oxygen availability (control and hypoxia) at each sampling time $\left(12,24,48\right.$ and 72 hours) within each nitrogen source $\left(\mathrm{NO}_{3}{ }^{-}\right.$and $\left.\mathrm{NH}_{4}{ }^{+}\right), \mathrm{whereas}$ lowercase letters compare the nitrogen sources at each sampling time within each oxygen condition. Different letters indicate significant differences with 0.05 probability. 

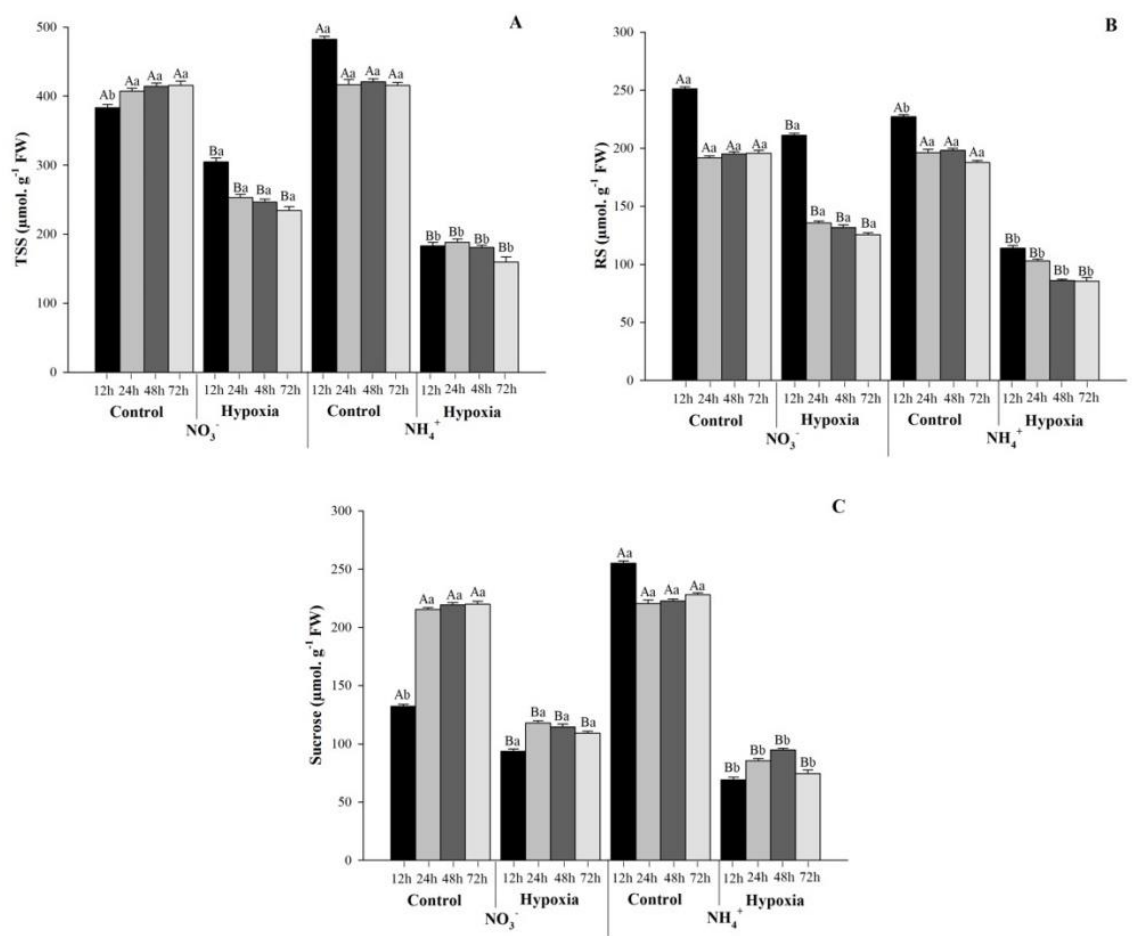

Fig 5. Effect of oxygen availability and of the nitrogen source in leaf content of total sugar soluble (A), reducing sugar (B) and sucrose (C) of rubber tree seedlings. Capital letters compare oxygen availability (control and hypoxia) at each sampling time (12, 24, 48 and 72 hours) within each nitrogen source $\left(\mathrm{NO}_{3}{ }^{-}\right.$and $\left.\mathrm{NH}_{4}{ }^{+}\right)$, whereas lowercase letters compare the nitrogen sources at each sampling time within each oxygen condition. Different letters indicate significant differences with 0.05 probability.
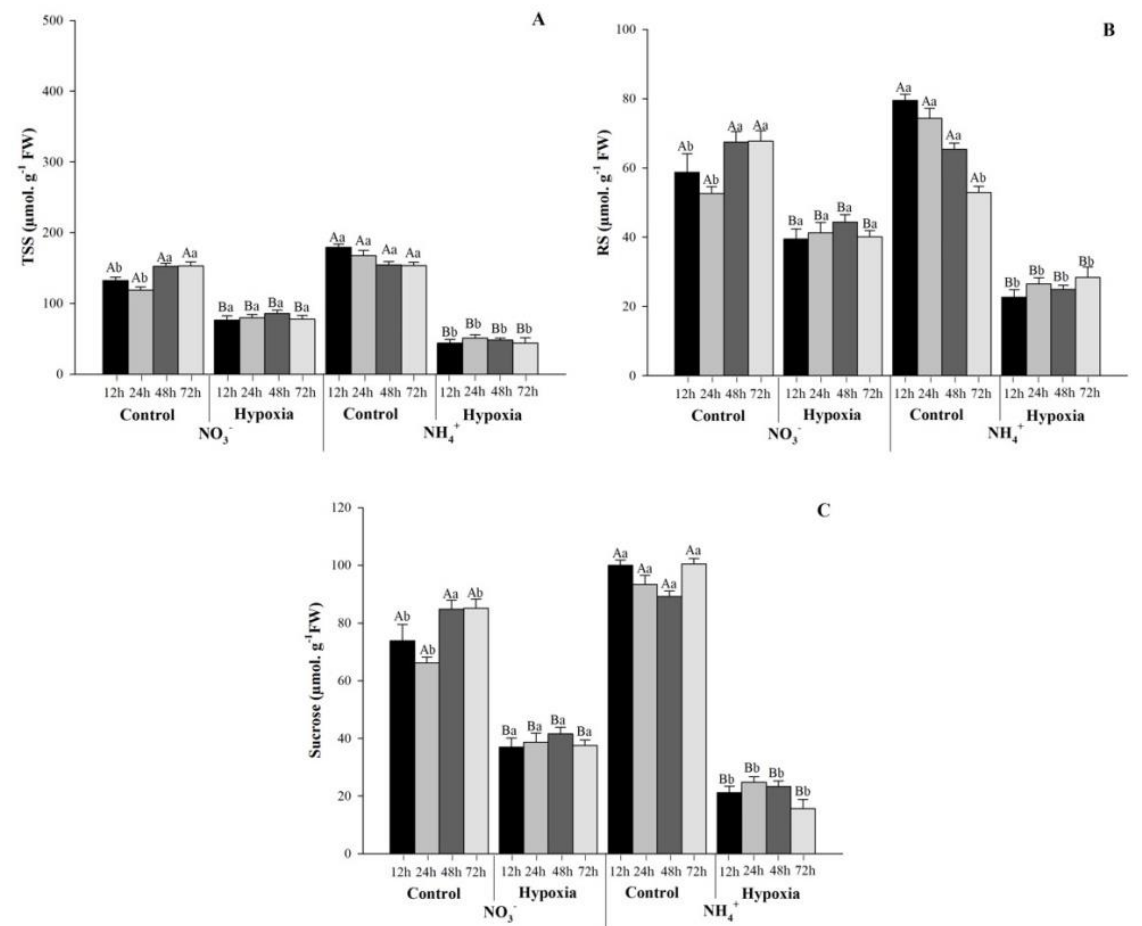

Fig 6. Effect of oxygen availability and of the nitrogen source in root content of total sugar soluble (A), reducing sugar (B) and sucrose (C) of rubber tree seedlings. Capital letters compare oxygen availability (control and hypoxia) at each sampling time (12, 24, 48 and 72 hours) within each nitrogen source $\left(\mathrm{NO}_{3}{ }^{-}\right.$and $\left.\mathrm{NH}_{4}{ }^{+}\right)$, whereas lowercase letters compare the nitrogen sources at each sampling time within each oxygen condition. Different letters indicate significant differences with 0.05 probability. 

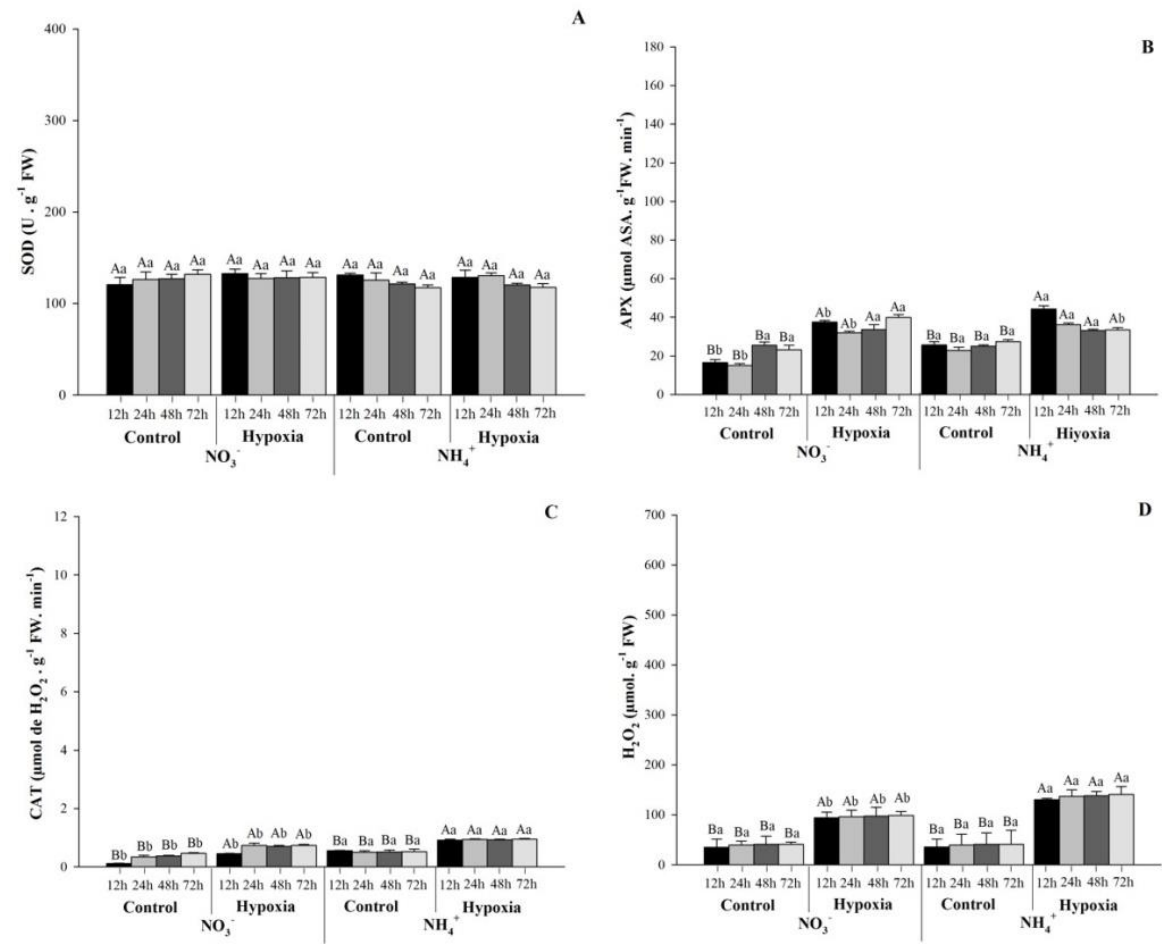

Fig 7. Effect of oxygen availability and of the nitrogen source in the activity of the enzymes superoxide dismutase (A), peroxidase ascorbate (B), catalase (C) and $\mathrm{H}_{2} \mathrm{O}_{2}$ content (D), in leaf of rubber tree seedlings. Capital letters compare oxygen availability (control and hypoxia) at each sampling time $\left(12,24,48\right.$ and 72 hours) within each nitrogen source $\left(\mathrm{NO}_{3}{ }^{-}\right.$and $\left.\mathrm{NH}_{4}{ }^{+}\right)$, whereas lowercase letters compare the nitrogen sources at each sampling time within each oxygen condition. Different letters indicate significant differences with 0.05 probability.
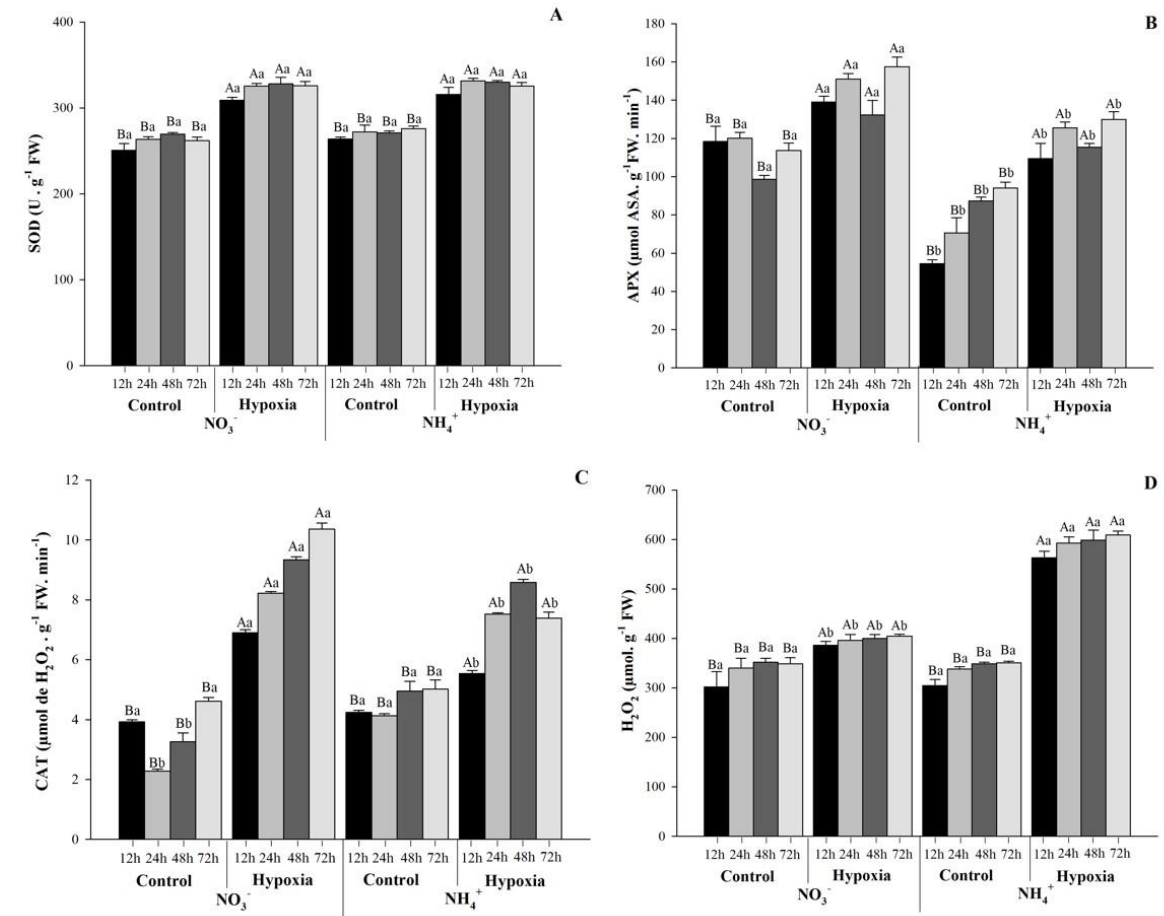

Fig 8. Effect of oxygen availability and of the nitrogen source in the activity of the enzymes superoxide dismutase (A), peroxidase ascorbate (B), catalase (C) and $\mathrm{H}_{2} \mathrm{O}_{2}$ content (D), in roots of rubber tree seedlings. Capital letters compare oxygen availability (control and hypoxia) at each sampling time $\left(12,24,48\right.$ and 72 hours) within each nitrogen source $\left(\mathrm{NO}_{3}{ }^{-}\right.$and $\left.\mathrm{NH}_{4}^{+}\right)$, whereas lowercase letters compare the nitrogen sources at each sampling time within each oxygen condition. Different letters indicate significant differences with 0.05 probability. 
treatment with $\mathrm{NH}_{4}^{+}$. In the leaves, value of $26 \mu \mathrm{mol} \mathrm{RS} . \mathrm{g}^{-1}$ FW. $\mathrm{h}^{-1}$ in the treatment $\mathrm{NO}_{3}^{-}$and $18 \mu \mathrm{mol} \mathrm{RS} . \mathrm{g}^{-1} \mathrm{FW} . \mathrm{h}^{-1}$ in the treatment with $\mathrm{NH}_{4}^{+}(70 \%)$ were observed (Fig. 3B). In

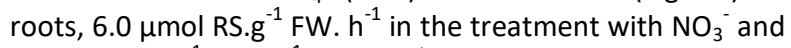
$3.0 \mu \mathrm{mol} \mathrm{RS} . \mathrm{g}^{-1} \mathrm{FW} . \mathrm{h}^{-1}$ with $\mathrm{NH}_{4}{ }^{+}(50 \%)$ were the results (Fig. 4B). Low $\mathrm{O}_{2}$ availability, also, provided reductions in CWIN activity. In the leaves, , when compared control and hypoxia, the reduction was on average, $40 \%$ in the plants treated with $\mathrm{NO}_{3}{ }^{-}$and $50 \%$ with $\mathrm{NH}_{4}{ }^{+}$(Fig. $3 \mathrm{C}$ ). In the roots, once again, $\mathrm{NO}_{3}{ }^{-}$had lower reduction than $\mathrm{NH}_{4}{ }^{+}$, the decrease was $29.0 \mu \mathrm{mol} \mathrm{RS} . \mathrm{g}^{-1} \mathrm{FW} . \mathrm{h}^{-1}$ to $22.0(25 \%)$ and 35.0 to 18.0 (49 $\%)$ respectively (Fig. 4 C).

\section{Total soluble sugars, reducing sugars and sucrose contents}

The carbohydrates as well as the invertase activities were significantly reduced after flooding induction, this was observed in leaves and roots for both nitrogen sources. When comparing control and hypoxia, in the $\mathrm{NO}_{3}{ }^{-}$treatment, in the leaves, total soluble sugars decreased of approximately $400 \mu \mathrm{mol} . \mathrm{g}^{-1} \mathrm{FW}$ to $250(37.5 \%)$ and of 400 $\mu \mathrm{mol} . \mathrm{g}^{-1} \mathrm{FW}$ to $190(52.5 \%)$ with $\mathrm{NH}_{4}^{+}$. In the roots, the decrease was approximately of $140 \mu \mathrm{mol}^{-1} \mathrm{FW}$ to 80 (42.8\%) with $\mathrm{NO}_{3}^{-}$and of $170 \mu \mathrm{mol} . \mathrm{g}^{-1} \mathrm{FW}$ to $50(70 \%)$ with $\mathrm{NH}_{4}^{+}$(Figs 5A and 6A).

Reducing sugars as part of total sugars also reduced sharply. Under normoxia, the results for both $\mathrm{NO}_{3}{ }^{-}$and for $\mathrm{NH}_{4}^{+}$were around $200 \mu \mathrm{mol} . \mathrm{g}^{-1} \mathrm{FW}$ in the leaves. In addition, about $65 \mu \mathrm{mol} . \mathrm{g}^{-1} \mathrm{FW}$ in the roots. However, in hypoxia, $\mathrm{NO}_{3}{ }^{-}$ showed values of $150 \mu \mathrm{mol} . \mathrm{g}^{-1} \mathrm{FW}$ in leaves and roots was of $40.0 \mu \mathrm{mol} . \mathrm{g}^{-1} \mathrm{FW}$. With $\mathrm{NH}_{4}^{+}$, the mean values were of 100 $\mu \mathrm{mol} . \mathrm{g}^{-1} \mathrm{FW}$ and of 25 respectively (Figs $5 \mathrm{~B}$ and $6 \mathrm{~B}$ ). Sucrose content was higher in control plants, in both tissues evaluated, hypoxic treatments leads to a decrease of approximately $50 \%$ in the treatment with $\mathrm{NO}_{3}{ }^{-}$and of $70 \%$ with $\mathrm{NH}_{4}^{+}$. (Figs $5 \mathrm{C}$ and $6 \mathrm{C}$ ). Practically, no differences in carbohydrate content between experimental times were observed.

\section{Antioxidant metabolism}

The SOD activity, in leaves, there was no difference between treatments (Fig. 7A). The result was approximately $126 \mathrm{U} \mathrm{g}^{-1}$ $\mathrm{FW}$, which remained constant throughout the experimental period. In the roots (Fig. 8A), when analyzing the effect of the $\mathrm{O}_{2}$ availability, there was a significant increase in SOD activity in plants under hypoxia, the values increased $22 \%$ (265 U g ${ }^{-1} \mathrm{FW}$ to 325) in both $\mathrm{NO}_{3}^{-}$and $\mathrm{NH}_{4}^{+}$treatments. In the treatments under hypoxia, there was significant increase in the APX activity compared to their respective controls, regardless of nitrogen source applied and evaluated tissue. The activity of this enzyme in the leaves under flooding, increased on average $75 \%$ in plants treated with $\mathrm{NO}_{3}{ }^{-}$and $40 \%$ in plants treated with $\mathrm{NH}_{4}^{+}$(Fig. 7B). In roots, higher APX activities were observed in flooded plants treated with $\mathrm{NO}_{3}{ }^{-}$. The results from this anion were significantly higher whether the $\mathrm{O}_{2}$ availability, and 24 hours after induction flooding, the activity reached $155 \mu \mathrm{mol}$ ASA. $\mathrm{min}^{-1}$. $\mathrm{g}^{-1} \mathrm{FW}$. While, in plants under hypoxia, subjected to $\mathrm{NH}_{4}{ }^{+}$, the maximum value was $130 \mu \mathrm{mol}$ ASA. $\mathrm{min}^{-1}$. $\mathrm{g}^{-1} \mathrm{FW}$ only after 72 hours (Fig. 8B). CAT activity, in both, in the leaves and in root tissue was enhanced under hypoxia. In the leaves of plants treated with $\mathrm{NO}_{3}^{-}$the CAT activity doubled, and increased $80 \%$ in the plants treated with $\mathrm{NH}_{4}{ }^{+}$(Fig. 7C). In the roots, under hypoxia, the increase in CAT activity, compared to the control was on average of $150 \%$ in plants treated with $\mathrm{NO}_{3}{ }^{-}$and $60 \%$ in plants treated with $\mathrm{NH}_{4}^{+}$(Fig. $8 \mathrm{C})$. In agreement with results previously described, the $\mathrm{H}_{2} \mathrm{O}_{2}$ content was higher in plants subjected to hypoxia, regardless of tissue evaluated and nitrogen source. In the leaves, under normoxia, no differences between treatments with $\mathrm{NO}_{3}^{-}$- and $\mathrm{NH}_{4}^{+}$were observed. However, under hypoxia, plants treated with $\mathrm{NH}_{4}^{+}$showed higher $\mathrm{H}_{2} \mathrm{O}_{2}$ production, overcoming treatment with $\mathrm{NO}_{3}{ }^{-}$in $40 \%$. In the roots, this variable has behaved similarly the leaves, although at much larger scale. In this plant tissue, $\mathrm{H}_{2} \mathrm{O}_{2}$ accumulation in the $\mathrm{NH}_{4}^{+}$presence and $\mathrm{O}_{2}$ absence, was even more significant, that is $65 \%$ higher when compared to treatment with $\mathrm{NO}_{3}{ }^{-}$(Figs. 7D and 8D).

It is worth mentioning also that for the three enzymes of the antioxidant system and $\mathrm{H}_{2} \mathrm{O}_{2}$ content, the data found in root tissue, overcame the results in leaf tissues in all evaluations regardless of the $\mathrm{O}_{2}$ availability and nitrogen source.

\section{Discussion}

Rubber tree plants to survive in areas where periodic flooding can happen - a common occurrence in native habitats of this species. This investigation about gas exchange, carbohydrate metabolism and antioxidant system enzymes in rubber tree seedlings subjected to $\mathrm{O}_{2}$ deficiency, showed that $\mathrm{NO}_{3}{ }^{-}$addition reduced effects of root hypoxia. Therefore, nitrate positively affects the natural plasticity of rubber tree plants. It is believed that $\mathrm{NO}_{3}^{-}$has effect on anaerobic metabolism. Its presence in the surrounding medium increases tolerance to flooding (Kaiser and Huber 2001).

In the present study was aimed to evaluate similar plants and as consequence of the experimental times (hours) no significant differences in the dry weight were detected. However, large metabolic changes in gas exchange, chlorophyll and sugar content and carbohydrate and antioxidant metabolism were found. In addition, was verified the plants response to the interaction nitrogen source versus low $\mathrm{O}_{2}$ availability.

Photosynthesis is the primary carbon source for higher plants when impaired under low $\mathrm{O}_{2}$ availability, it affects the entire dynamics of the carbon metabolism. At leaf level, stomatal conductance decline to prevent loss water along with the decrease of Rubisco activity constitutes a first response against $\mathrm{O}_{2}$ deprivation. (Carvalho et al. 2015a), also observed reduction of $33 \%$ and $71 \%$ in photosynthesis of rubber tree seedlings treated with $\mathrm{NO}_{3}-$ and $\mathrm{NH} 4+$ respectively, after 21 days under flooding. Plants treated with ammonium showed large reduction in stomatal conductance and transpiration resulting in decrease of water absorption by roots and a lower $\mathrm{CO}_{2}$ diffusion rate into the leave. Consequently, Rubisco is affected by the reduction of leaf hydric potential or lack of substrate. In fact, although variable, the preservation of the photosynthetic activity is associated with plants tolerance to flooding (Arbona et al. 2009). In this work, the $\mathrm{CO}_{2}$ assimilation was higher in plants treated with $\mathrm{NO}_{3}{ }^{-}$which showed greater conservation of the photosynthetic process, under $\mathrm{O}_{2}$ deficit. Carbohydrates are the main carbon stocks 
of plants and their quantities, maintain your metabolism at appropriate levels and the correct partitioning of these molecules associated with energy are prerequisites for the stresses survival (Goggin 2007). The results showed that when under hypoxia, a significant decrease in soluble sugars concentration, particularly sucrose, is accompanied by a reduction in activity of all isoforms invertase and therefore the amount of reducing sugars. Some explanations are possible for the decline of activity of invertase in wetland environments, including pre-existing enzymes degradation and substrate limitation to induce enzyme. Thus, the significant activity decrease of soluble and insoluble invertase treatment with $\mathrm{NH}_{4}^{+}$probably due to substrate limitation in these plants. Metabolic adaptations to hypoxia include the down-regulation of storage metabolism (van Dongen et al. 2004), the energy conserving shift from the invertase to the sucrose synthase route of sucrose degradation (Huang et al. 2008) thereby using pyrophosphate rather than ATP, and a decrease in mitochondrial respiratory activity at low oxygen (Zabalza et al. 2009). Decreases in vacuolar invertase activity are associated with responses to low oxygen and droughtinduced early seed abortion (Andersen et al. 2002). In contrast to the CWIN, VIN and the NIN is not glycosylated invertase so the NIN activity is inhibited by breaking sucrose. Enzymes involved in sucrose breakdown are; soluble invertase, neutral invertase and sucrose synthase (Komor 2000). The futile cycle of sucrose, and constant cleavage and re-synthesis of the molecule have been proposed as the mechanism that allows greater flexibility and control over the carbohydrate metabolism and its partition. This cycling promotes the unloading phloem through a sucrose concentration gradient (Rontein et al. 2002).

The changes in demand under adverse conditions alter carbohydrate carbon partitioning in accordance with the relation source-drain, and the charge potential and are dependent on biochemical signaling pathways and molecular complex. Among the enzymatic pathways affected, those involved in sucrose degradation have been extensive study object. Thus, along with vascular changes in physical properties, as well as the loading and transport in the phloem, contribute to different responses observed. Therefore, catabolic pathways regulation contributes to better responses to stress (Bailey-Serres and Voesenek 2008). In our study, higher SOD and APX activity and lower $\mathrm{H}_{2} \mathrm{O}_{2}$ content was observed in hypoxic plants treated with nitrate. The efficient action of these enzymes is an extremely important component of physiological tolerance, since their actions prevent free radicals from damaging cells and membranes organelles such as mitochondria and chloroplasts. Second Allen et al. (1997), increases in antioxidant enzyme expression may increase tolerance to oxidative stress, which increases in low $\mathrm{O}_{2}$ availability conditions. Under low $\mathrm{O}_{2}$ availability excessive reducing power and surfeit of ATP leads to cell super reduction, triggering the production of reactive oxygen species (ROS) which are highly detrimental to cell structures. Increased enzyme activity (such as SOD and APX) associated with ROS deletion is thus related with increased stress tolerance in plants exposed to adverse environmental conditions (Giannakoula et al. 2010). Rubber tree plants under hypoxia presented higher antioxidant enzymes activity, especially in plants treated with nitrate. Nitrate application reduces the formation of reactive oxygen species because NR consumes $\mathrm{NADH}$ reducing power, preventing that accumulates and causes over cellular reduction. Furthermore, nitrate improves the efficiency of enzymes SOD, CAT and APX controlling the action of free radicals $\left(\mathrm{H}_{2} \mathrm{O}_{2}\right)$ and oxidative stress.

\section{Materials and Methods}

\section{Plant cultivation and experimental conditions}

Rubber trees were grown from seed in a greenhouse $\left(21^{\circ} 14^{\prime} \mathrm{S}, 45^{\circ} 00^{\prime} \mathrm{W}\right.$, altitude $\left.918 \mathrm{~m}\right)$. Environmental conditions inside the greenhouse were: mean air temperature between $18^{\circ} \mathrm{C}$ (minimum) and $40^{\circ} \mathrm{C}$ (maximum) with an average temperature of $29^{\circ} \mathrm{C}$; average air relative humidity around $56 \%$; maximum photosynthetic photon flux density (PPFD) of $1500 \mu \mathrm{mol} \mathrm{m}^{-2} \cdot \mathrm{s}^{-1}$ and $12 \mathrm{~h}$ photoperiod. Seeds (cultivar GT1) previously selected for size and weight were germinated in sand. Fifteen days after germination, seedlings of similar height and morphological characteristics were transplanted to pots (5L) filled with nutrient solution of Bolle-Jones (1957)1/2 strength. The solution volume was refilled daily. The $\mathrm{pH}$ of the solution was adjusted daily to $5.5 \pm 0.5$ and solutions were completely replaced at weekly intervals.

\section{Treatments and harvesting}

When plants were 6 months-old they were divided into four treatments consisting of two nitrogen source in nutrient solution $\left(8 \mathrm{mM}\right.$ nitrate $\left(\mathrm{KNO}_{3}\right)$ and $8 \mathrm{mM}$ ammonium $\left(\left(\mathrm{NH}_{4}\right)_{2} \mathrm{SO}_{4}\right)$ and two conditions of oxygen availability (control plants, kept under normoxia and flooded plants, kept under root hypoxia). The experiment was conducted over a period of 3 days, measurements of gas exchange and biochemical analyzes (sample plant material: leaf and root) performed at twelve (12), twenty four (24), forty-eight (48) and seventy-two (72) hours after treatment induction. Sampling was carried out simultaneously to allow accurate comparisons among gas exchanges, carbohydrate metabolism enzymes activity (invertase isoforms and carbohydrate content) and antioxidant metabolism enzymes activity (SOD, CAT, APX).

\section{Shoot and root dry weight}

The seedlings were divided into roots and shoots. The plant material was dried at $70{ }^{\circ} \mathrm{C}$ to constant weight and the dry weight measured.

\section{Gas exchange and chlorophyll content measurements}

Gas exchange measurements were performed in the third fully expanded leaf was monitored throughout the experiment. For three days $(12,24,48$ and 72 hours after treatment induction.) gas exchange was evaluated at 09:00 or 10:00 in the central leaflet. Net $\mathrm{CO}_{2}$ assimilation rate $\left(P_{\mathrm{N}}\right)$, stomatal conductance $\left(g_{\mathrm{s}}\right)$, intracellular and environmental concentrations of $\mathrm{CO}_{2}(\mathrm{Ci}$ and $\mathrm{Ca})$ and the transpiration rate (E) were regularly evaluated using a portable gas exchange system (IRGA LI-6400XT, LI-COR, Lincoln, NE, USA). The 
chlorophyll content was determined using the chlorophyll FT GREEN LLC atLEAF ${ }^{+}$model.

\section{Carbohydrate metabolism enzyme assay (CWIN, VIN and NIN) and sugar measurement}

Enzyme extract was obtained with liquid nitrogen mortification of $0.5 \mathrm{~g}$ leaf blades or roots, to which was added $1.5 \mathrm{~mL}$ of extraction buffer containing potassium phosphate buffer $100 \mathrm{mM}$ (pH 7.5), PMSF $1 \mathrm{mM}, \mathrm{MgCl}_{2} 5$ $\mathrm{mM}$ and DTT $1 \mathrm{mM}$. The extract was centrifuged at $18000 \mathrm{~g}$ per 20 min at 4 ㅇ (Cairo et al. 2009). Supernatant fraction was used to analyze the soluble activity (VIN and NIN). Extract for insoluble activity (CWIN) was obtained from pellet fraction according to Fahrendorf; Beck (1990). Activities of vacuolar (VIN) and cytoplasmic (NIN) invertases were determined with $\mathrm{MgCl}_{2} 5 \mathrm{mM}$ e sucrose $200 \mathrm{mM}$, phosphate buffer $(0,4 \mathrm{M})$ at $\mathrm{pH} 7.5$ for neutral invertase or

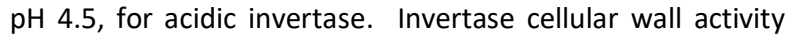
(CWIN) was determined with sodium acetate buffer 0,1 M e $\mathrm{pH} 3,5, \mathrm{MgCl}_{2} 5 \mathrm{mM}$ and sucrose $200 \mathrm{mM}$. The reactions proceeded for $1 \mathrm{~h}$ at 37을 $\mathrm{C}$ when the formation of reducing sugars was analyzed (Miller 1959). Carbohydrates extraction was performed from $1000 \mathrm{mg}$ of dry weight were homogenized in $5 \mathrm{~mL}$ of potassium phosphate buffer 100 $\mathrm{mM}(\mathrm{pH} \mathrm{7,0)}$ and then placed in a water bath for $30 \mathrm{~min}$ at $40{ }^{\circ} \mathrm{C}$. Homogenate was centrifuged at $5,000 \mathrm{~g}$ for $10 \mathrm{~min}$ and the supernatant was collected. The process was repeated twice and supernatants were combined. Sucrose and total soluble sugars were quantified as described by Dische (1962), and level of reducing sugars was quantified according to Miller (1959).

\section{Antioxidant metabolism enzymes activity (SOD, CAT, APX) and $\mathrm{H}_{2} \mathrm{O}_{2}$ content}

Enzyme extract was obtained with liquid nitrogen mortification of $0.2 \mathrm{~g}$ leaf blades or roots, to which was added $1.5 \mathrm{~mL}$ of extraction buffer containing potassium phosphate buffer $400 \mathrm{mM}$ (pH 7.8), EDTA $10 \mathrm{mM}$, ascorbic acid $200 \mathrm{mM}$ and $22 \mathrm{mg}$ PVPP. The extract was centrifuged at $13000 \mathrm{~g}$ per $10 \mathrm{~min}$ at 4 o C. Supernatant was used to analyze the superoxide dismutase (SOD), catalases (CAT) and ascorbate peroxidases (APX) enzymes (Biemelt et al. 1998). SOD activity (EC 1.15.1.1) was evaluated by the ability of the enzyme to inhibit photo-reduction of nitroblue tetrazolium (NBT), as proposed by Giannopolitis and Ries (1977). CAT (EC 1.11.1.6) was evaluated according to Havir and McHale (1987) and APX activity (EC 1.11.1.11) was determined according Nakano and Asada (1981). Lastly, $\mathrm{H}_{2} \mathrm{O}_{2}$ content was determined according Velikova et al. (2000).

\section{Statistical analysis and experimental design}

The experiments were arranged in a completely randomized design (CRD) in a factorial arrangement $(2 \times 2 \times 4)$. The experiment had four treatments and four time points (12, 24, 48 and 72 hours) for stress measurements with four replicates, totaling 64 plants. Data were analyzed using analysis of variance (ANOVA), and the means were compared using the Scott-Knott test $(p \leq 0.05)$.

\section{Conclusion}

Carbon assimilation, carbohydrate metabolism, sugar distribution and antioxidant system action are strongly affected by hypoxia in rubber tree plants. Plants treated with $\mathrm{NH}_{4}{ }^{+}$are more sensitive to hypoxia than plants treated with $\mathrm{NO}_{3}{ }^{-} . \mathrm{NH}_{4}{ }^{+}$treatment presented greater reduction of the photosynthesis and carbohydrate content, lower efficient antioxidant activity for the removal of oxygen reactive species. Therefore, $\mathrm{NO}_{3}{ }^{-}$addition reduces damage caused by oxygen deficiency promoting response to hypoxia was less intense than with $\mathrm{NH}_{4}^{+}$thus $\mathrm{NO}_{3}{ }^{-}$increase the tolerance of rubber tree plants to stress.

\section{Acknowledgments}

The authors are grateful to the Conselho Nacional de Desenvolvimento Científico e Tecnológico (CNPq; Brasília, DF- Brazil), Fundação de Amparo à Pesquisa de Minas Gerais (FAPEMIG; Belo Horizonte, MG-Brazil) and Coordenação de Aperfeiçoamento de Pessoal de Nível Superior (CAPES; Brasília, DF-Brazil) for financial support.

\section{Conflict of interest}

The authors declare that they have no conflicts of interest.

\section{References}

Allegre A, Silvestre J, Morard P, et al (2004) Nitrate reductase regulation in tomato roots by exogenous nitrate: a possible role in tolerance to long-term root anoxia. J Exp Bot. 55:2625-2634

Allen RD, Webb RP, Schake SA (1997) Use of Transgenic Plants to Study Antioxidant Defenses. Free Radic Biol Med. 23:473-479.

Andersen MN, Asch F, Wu Y, et al (2002) Soluble invertase expression is an early target of drought stress during the critical, abortion-sensitive phase of young ovary development in maize. Plant Physiol. 130:591-604.

Arbona V, López-Climent MF, Pérez-Clemente RM, GómezCadenas A (2009) Maintenance of a high photosynthetic performance is linked to flooding tolerance in citrus. Environ Exp Bot. 66:135-142.

Bailey-Serres J, Voesenek LACJ (2008) Flooding Stress: Acclimations and Genetic Diversity. Annu Rev Plant Biol. 59:313-339.

Biemelt S, Keetman U, Albrecht G (1998) Re-Aeration following Hypoxia or Anoxia Leads to Activation of the Antioxidative Defense System in Roots of Wheat Seedlings. Plant Physiol. 116:651-8.

Bolle-Jones EW (1957) Copper: Its effects on the growth and composition of the rubber plant (Hevea brasiliensis). Plant Soil. 9:160-178.

Cairo PAR, Oliveira LEM, Mesquita AC, Cunha RL (2009) Activity of rubisco and enzymes of sucrose synthesis and hydrolysis associated to latex productivity, in rubber tree clones [Hevea brasiliensis (Willd ex. Adr. de Juss.) Muell.Arg] cultivated in Lavras, MG. Ciênc agrotec. (Impr) 33:369-376. 
Carvalho PA, Oliveira LEM, et al (2015b) Nitrogen metabolism in the roots of rubber tree (Hevea brasiliensis) plants supplied with nitrate or ammonium as nitrogen source during hypoxia. Austral. J Crop Sci. 9:1278-1285.

Carvalho PA, Lira JMS, de Oliveira LEM, et al (2015a) Nitrate Addition Improves Photosynthesis and Flooding Tolerance of Rubber Tree Plants. Austral. J Crop Sci. 9:684-689

Dische Z (1962) Methods in carbohydrates chemistry. In: R. Whistler MW (ed) Methods in carbohydrates chemistry, 2nd edn. Academic Press, New York, pp 478-512

Escobar MA, Geisler DA, Rasmusson AG (2006) Reorganization of the alternative pathways of the Arabidopsis respiratory chain by nitrogen supply: opposing effects of ammonium and nitrate. Plant J. 45:775-88.

Essmann J, Schmitz-Thom I, Schön H, et al (2008) RNA interference-mediated repression of cell wall invertase impairs defense in source leaves of tobacco. Plant Physiol. 147:1288-99.

Giannakoula A, Moustakas M, Syros T, Yupsanis T (2010) Aluminum stress induces up-regulation of an efficient antioxidant system in the Al-tolerant maize line but not in the Al-sensitive line. Environ Exp Bot. 67:487-494.

Giannopolitis CN, Ries SK (1977) Superoxide Dismutases: II. Purification and Quantitative Relationship with Watersoluble Protein in Seedlings. Plant Physiol. 59:315-318.

Goggin FL (2007) Plant-aphid interactions: molecular and ecological perspectives. Curr Opin Plant Biol. 10:399-408.

Havir EA, McHale NA (1987) Biochemical and Developmental Characterization of Multiple Forms of Catalase in Tobacco Leaves. Plant Physiol. 84:450-455.

Hong-Bo S, Li-Ye C, Ming-An S (2008) Calcium as a versatile plant signal transducer under soil water stress. Bioessays. 30:634-41.

Horchani F, Aschi-Smiti S, Brouquisse R (2010) Involvement of nitrate reduction in the tolerance of tomato (Solanum lycopersicum L.) plants to prolonged root hypoxia. Acta Physiol Plant. 32:1113-1123.

Huang S, Colmer TD, Millar AH (2008) Does anoxia tolerance involve altering the energy currency towards PPi Trends Plant Sci. 13:221-227.

Irfan M, Hayat S, Hayat $Q$, et al (2010) Physiological and biochemical changes in plants under waterlogging. Protoplasm.241:3-17.

Jaleel CA, Riadh K, Gopi R, et al (2009) Antioxidant defense responses: physiological plasticity in higher plants under abiotic constraints. Acta Physiol Plant. 31:427-436.

Kaiser WM, Huber SC (2001) Post-translational regulation of nitrate reductase: mechanism, physiological relevance and environmental triggers. J Exp Bot. 52:1981-1989.
Komor E (2000) Source physiology and assimilate transport: the interaction of sucrose metabolism, starch storage and phloem export in source leaves and the effects on sugar status in phloem. Funct Plant Biol. 27:497.

Kozlowski TT (1997) Responses of woody plants to flooding and salinity. Tree Physiol. 17:490-490.

Kreuzwieser J, Papadopoulou E, Rennenberg H (2004) Interaction of Flooding with Carbon Metabolism of Forest Trees. Plant Biol. 6:299-306.

Medri ME, Ferreira AC, Kolb RM, et al (2007) Alterações morfoanatômicas em plantas de Lithraea molleoides (Vell.) Engl. submetidas ao alagamento. Acta Sci Biol Sci. 29:1522.

Miller GL (1959) Use of Dinitrosalicylic Acid Reagent for Determination of Reducing Sugar. Anal Chem. 31:426-428.

Nakano Y, Asada K (1981) Hydrogen Peroxide is Scavenged by Ascorbate-specific Peroxidase in Spinach Chloroplasts. Plant Cell Physiol. 22:867-880.

Nunes-Nesi A, Fernie AR, Stitt M (2010) Metabolic and signaling aspects underpinning the regulation of plant carbon nitrogen interactions. Mol Plant. 3:973-96.

Patterson K, Cakmak T, Cooper A, et al (2010) Distinct signalling pathways and transcriptome response signatures differentiate ammonium- and nitrate-supplied plants. Plant Cell Environ. 33:1486-501

Pompeu GB, Gratão PL, Vitorello VA, Azevedo RA (2008) Antioxidant isoenzyme responses to nickel-induced stress in tobacco cell suspension culture. Sci Agric. 65:548-552.

Rolland F, Baena-Gonzalez E, Sheen J (2006) Sugar sensing and signaling in plants: conserved and novel mechanisms. Annu Rev Plant Biol. 57:675-709.

Rontein D, Basset G, Hanson AD (2002) Metabolic Engineering of Osmoprotectant Accumulation in Plants. Metab Eng. 4:49-56.

Thomas AL, Sodek L (2005) Development of the nodulated soybean plant after flooding of the root system with different sources of nitrogen. Brazilian J Plant Physiol. 17:291-297.

Van Dongen JT, Roeb GW, Dautzenberg M, et al (2004) Phloem import and storage metabolism are highly coordinated by the low oxygen concentrations within developing wheat seeds. Plant Physiol. 135:1809-21.

Velikova V, Yordanov I, Edreva A (2000) Oxidative stress and some antioxidant systems in acid rain-treated bean plants. Plant Sci. 151:59-66.

Zabalza A, van Dongen JT, Froehlich A, et al (2009) Regulation of respiration and fermentation to control the plant internal oxygen concentration. Plant Physiol. 149:1087-98. 